\title{
Postkolonialne Polski: szkic z niepewnej natury
}

\author{
Postcolonial Polands - an outline \\ of uncertain nature
}

\author{
|| $\begin{aligned} & \text { Adam Kubiak } \\ & \text { Instytut Filozofii Uniwersytetu Rzeszowskiego }\end{aligned}$
}

\begin{abstract}
The paper aims to address a few selected, very important, yet still strongly contested layers and perspectives of Polish postcolonial discourse within a context of an actual local social and cultural problems (and in consequence: its political narrative). Social divisions and using postcolonial narrations and languages both as a tool to reinforce (or restoration) them and, on the other hand: resistance, in particular. The main goal of the paper is to show, in perspective, how the social problems became more present and vocal and the whole local „postcolonial debate” is strongly shifting form its predominant literature and cultural source of reflection. Facing, as author argues, the most challenging topic: postcolonial reactionary narrative.
\end{abstract}

Key words: postcolonial narrative, reactionary postcolonialism, class divisions, intelligentsia, Poland, social change, social exclusion

Streszczenie: Tekst poświęcony jest kilku wybranym, nader istotnym i wciąż silnie spornym warstwom i perspektywom dyskursu postkolonialnego w Polsce, w kontekście współczesnych, rzeczywistych problemów społecznej i kulturowej lokalności. W konsekwencji zaś także: ich politycznym urzeczywistnieniom dyskursywnym. W centrum pracy znajdują się podziały społeczne i użytek jaki czynią narratorzy tegoż dyskursu, traktowanego czy to jako narzędzie do ich umocnienia (bądź restauracji) jak i oporu emancypacyjnego Głównym motywem, w tej perspektywie, jest przeniesienie uwagi badawczej na problematykę społeczną, jaka dokonała się w tejże „debacie postkolonialnej” stając się w niej coraz silniej obecna i donośna. W konsekwencji, w sposób znaczący odchodząc od typowo literaturoznawczych kulturoznawczych i literackich źródeł tego nurtu refleksji. Tym sposobem, badacze postkolonialni stają wobec jednego z najsilniejszych jego wyzwań jakim jest, wedle autora: reakcyjna narracja postkolonialna.

Słowa kluczowe: narracja postkolonialna, reakcyjny postkolonializm, zróżnicowanie klasowe, inteligencja, Polska, zmiana społeczna, wykluczenie społeczne 


\section{Wprowadzenie: perspektywy dyskusji, warstwy sporów}

Problem dyskusji o specyfice peryferyjności czy wręcz prowincjonalności w odniesieniu do Polski czy - ogólniej - całego regionu (Europy Środkowo-Wschodniej) uwikłany jest w kilka przenikających się płaszczyzn, na jakich bywał i bywa rozważany. Warto pamiętać, iż nie zamykają się one w literackich czy kulturowych analizach, ale mają konkretne polityczne konsekwencje. Przykładem takiego wpływu jest choćby rola polskiej dyplomacji w konflikcie ukraińskim oraz zmienne (w zależności od dominującego elementu politycznego) relacje z Unią Europejską, której rola, i Polski w niej obecność, interpretowana jest raz w charakterze emancypacyjnym, kiedy indziej zaś jako rodzaj kolonizacji, wreszcie w niektórych retorykach sama Unia bywa traktowana jako terytorium do „chrześcijańskiej kolonizacji” bądź rekonkwisty. W polityce wewnętrznej nader wyraźnym i aktualnym przykładem jest na przykład status Polskiej Rzeczpospolitej Ludowej i jej dziedzictwa materialnego i kulturowego.

Drugim elementem, który należy mieć na uwadze - a z osobliwą, choć zrozumiałą ze względu na komfort debatujących, uporczywością umyka on najczęściej w takich sporach - jest pozycja, z jakiej się poszczególni autorzy wypowiadają. Wewnętrzne debaty są oczywiście debatami peryferyjnymi, prowincjonalnymi. Prowadzone są z faktycznie podrzędnego miejsca niezależnie od przeświadczeń ich uczestników (a także niezależnie od tego, czy toczą się w języku peryferii: po polsku, czy też są „umiędzynarodowione”) wraz z całym charakterystycznym bagażem. Do jego instrumentarium należy skłonność do przeceniania siły podrzędności i w związku z tym akcentowania czy to „kolonialnej mentalności” (szczególnie w odniesieniu do własnych podrzędnych, znajdujących się poniżej dyskutantów), czy skłonności do kolaboracji („kompradorstwa”) podporządkowanych, lokalnych elit (tych zwłaszcza o odmiennych zapatrywaniach). Tak samo jak i - z drugiej strony - nie mniej przesadne akcentowanie postkolonialnej czy postzależnościowej, wyzwoleńczej sprawczości podporządkowanych w tym szczególnie siły sprawczej tych, którzy takowe przeświadczenia aktualnie głoszą. Obie te perspektywy, instrumentalnie użyteczne w zakresie etykietowania przeciwników, wydają się w najlepszym przypadku ułomne i ograniczone.

Trzecim elementem jest ta okoliczność, że kondycja peryferyjna, skutki podporządkowanego statusu nie są tematami „abstrakcyjnymi”, stanowią istotną część lokalnych i osobistych historii nieograniczających się do „historii" właśnie (więc ustandardyzowanego i postulatywnie dobrze kontrolowanego przekazu np. szkolnego) ani też wyłącznie do przedmiotu literatury eksploatującej wątki podporządkowania, nieprzystawalności, zależności, buntu czy wspomnianego „kompradorstwa”. Tematyka ma różne postaci i dość rozległy zakres. Wpisują się w nią zarówno np. publicystyczne teksty Arkadiusza Pacholskiego (Pacholski 2012), stwierdzającego, że „W rzeczywistości największą tragedią, jaka dotknęła kiedykolwiek Polaków, tragedią, 
dużo większą i dotkliwszą niż tamte wszystkie razem wzięte, było niewolnictwo polskich chłopów", jak i analizy Michała Buchowskiego (Buchowski, 2006) dotykające istotnej problematyki wewnętrznych zależności i podporządkowań, czy wręcz: wewnętrznej kolonizacji zarówno w postaci idiomu terytorialnego (jego popularną postacią jest „Polska B”), jak i praktyk społecznych. Zwracał uwagę Buchowski:

Co najmniej trzy relatywnie równoległe idiomy wewnętrznej, społecznej orientalizacji są łatwe do zidentyfikowania: miejskie vs. wiejskie, wykształceni vs. niewykształceni i zwycięzcy vs. przegrani w transformacji. W tym sensie eksplozja globalnego kapitalizmu przekłada się na to jak klasyczny orientalizm, wyrażany w mentalnych geografiach, w pewien sposób, urzeczywistnia się na poziomie lokalnym (narodowym). Taki wewnętrzny, udomowiony orientalizm nie może zostać zatrzymany w osobnej, nawet jeśli zlokalizowanej, przestrzeni, skoro Inny może żyć pośród „nas”, zamieszkiwać to samo miejsce, mówić tym samym językiem i wierzyć w tego samego Boga (Buchowski 2006, 466-467).

Przedstawiciele warstw podporządkowanych (tekst pisany był przed spopularyzowaniem kategorii „prekariatu” i dotyczy robotników, mieszkańców wsi i innych „nieprzystosowanych do przemian” w kontekście końca XX wieku) w konsekwencji:

nie są klasyfikowani jako normalni lecz opisywani w kategoriach uwłaczających jako populistyczny lumpenproletariat pozbawiony moralności. Członkowie tych grup muszą zostać zdyscyplinowani i przekształceni jako osoby, aby móc pasować do ,kapitalistycznej normalności', oczywistej i nieoznaczonej kategorii (Buchowski 2008, 469).

Tym samym, język opisujący tych, którzy nie potrafili bądź nie mogli odnaleźć się w przemianach lat 90., przyjął postaci orientalizacyjne aż do de facto rasistowskich.

Kolejnym często podnoszonym i budzącym dość osobliwe kontrowersje problemem jest podwójny status historycznych wcieleń Polski (jako państwa), jej kolonizująco-skolonizowany charakter. Osobliwość tej kontrowersji wynika z wewnętrznych narracyjnych sprzeczności prowadzących do opowieści o „pokojowym kulturowym kolonializmie” czy eksploatujących wątek sielskości życia folwarcznego lub restauracji „sarmatyzmu”1 jako kategorii identyfikującej polską („lepszą”, gdyż wedle autorów tych imaginacji pozbawioną przemocy) wersję kulturowej dominacji. Wizja pokojowego, pozbawionego dążeń ekspansyjnych błogiego imperium, którą szkicuje np. Thompson (Thompson 2010), jako że „Sarmatyzm nie jest zorientowany ani

\footnotetext{
1 Debata dotycząca restauracji kategorii „sarmatyzmu”, funkcjonującej zarówno jako literacki idiom, popularny element wyobraźni jak i idiom polityczny, jest więcej niż pokaźna. Pod auspicjami (m.in.) Ewy Thompson funkcjonuje czasopismo Sarmatian Review odwołujące się tak programowo, jak i tytułem do idei obrony natywnej niewinności (gdzie „sarmatyzm” funkcjonuje jako znak łączący). Tematyce sarmackiej i jej osobliwościom cały numer poświęciło także w 2015 roku czasopismo Teksty Drugie (2015/1 „Zwrot sarmacki”). Interesującą analizę (m.in.) sarmatyzmu jako kategorii narracyjnej w twórczości Krzysztofa Koehlera, jednej z ważniejszych postaci dla współczesnego funkcjonowania tej idiomatyki i jej wyobraźni, przedstawił np. Paweł Bochuszewicz (Bochuszewicz 2011, 2014).
} 
na podboje, ani na podporządkowanie się cesarzowi, zamiast tego ceni republikanizm” całkowicie pomija okoliczność, że termin „sarmatyzm” ujmuje treść ściśle rasistowską (odrębność nie po prostu „etniczną”, lecz „rasową” właśnie szlachty od szeroko rozumianego „ludu miejscowego”, ongiś wedle legendy przez nią podbitego) ${ }^{2}$ i nie sposób go uznać tylko za „brzydki megalomański wyjątek” od sielankowej reguły. Opiewane przez „sarmatów” spokojne życie oparte było wszak na niewolniczej pracy i zamkniętej, postulatywnie całkowicie pozbawionej mobilności strukturze podziałów społecznych. „Sielanka” możliwa była do urzeczywistnienia (choćby i w literacko-fantastycznej formie) dzięki wykluczeniu i poniżeniu chłopów i mieszczan.

Uznawanie, słuszne skądinąd, Rzeczpospolitej Obojga Narodów za lokalnego hegemona musi nieść za sobą konsekwencje uznania imperializmu tegoż właśnie hegemona już choćby z tej przyczyny, że hegemonia polityczna tenże imperializm w sobie zawiera. Raczej nieprzypadkowo jedno z centralnych rosyjskich świąt celebruje opuszczenie przez polską załogę Kremla, która nie przebywała tam przecież z misją kulturalną, przedstawiając dobrodziejstwa litewskiej i koronnej kuchni z całą sarmacką życzliwością, na jaką było ją stać.

Wątek ten podniósł np. Jan Sowa (Sowa 2010) w szeroko dyskutowanym Fantomowym ciele króla. Książka wywołała kontrowersje i polemiki. Jednym z trudnych do dyskutowania elementów była rekonstrukcja historycznej Rzeczpospolitej jako jednego z kolonialnych opresorów, co naruszało istotne tabu wzbraniające postrzegania i określania Polski (w jakiejkolwiek postaci - co jest jedną z przyczyn, dla których PRL bywa dziś z taką uporczywością wymazywana z polskiej historii) i Polaków inaczej niźli w tonacji sentymentalno-heroicznej i wyłącznie w roli ofiar (jeśli nie „sprawiedliwych zwycięzców”). Wątek ten wcześniej podnosił Daniel de Beauvois (Beauvois 2005) w Trójkącie ukraińskim, książce poświęconej relacjom między szlachtą, w tym szlachtą zdegradowaną (i procesom tej degradacji) a chłopstwem w obliczu rosnącej presji Imperium Rosyjskiego po powstaniu styczniowym, szkicując między innymi zarówno dramatyczne nierówności wewnątrz samego stanu szlacheckiego, jak i kolonialne relacje między państwem a miejscowymi.

Wspomniane wyżej wątki zazębiają się, tworząc dość charakterystyczny i mocno chaotyczny obraz, jakim jest, niezależnie od kolejnych aktów dyscyplinujących, takich jak publikacje, sankcje podręcznikowe czy akty prawne, „postkolonialna Polska” albo raczej „postkolonialny dyskurs” w niej się odbywający. Nie ułatwia tej sytuacji okoliczność, że jednym z fundamentalnych elementów, wokół których bywają one zorganizowane, np. „Kresy”

\footnotetext{
Termin „rasistowski” może słusznie wydawać się anachronizmem w odniesieniu do zjawisk funkcjonujących przed jego (rasizmu) „naukowym ugruntowaniem” w wieku XIX. Jesli jednak przyjmiemy, że fundamentalnym, definiującym elementem doktryn (bądź koncepcji czy tylko przesądów) rasistowskich jest ontologiczna różnica między „rasami”, zatem różnica, która zawiera się w samym bycie przedstawicieli „rasy” (bądź „ras”) a de facto włącznie z antycznym, greckim wyobrażeniem barbaros takie rozumienie jest implicite zawarte $\mathrm{w}$ tych dyskursach, ekstrapolacja tego terminu staje się anachronizmem - przynajmniej retorycznie - akceptowalnym.
} 
czy „kresowe dziedzictwo” są - jak słusznie zwrócił uwagę np. Skórczewski (Skórczewski 2014, 440) - obiektami funkcjonującymi czysto imaginacyjnie. Ich empiryczne pozostałości (potomkowie przesiedleńców zamieszkujący dziś głównie zachodnie i północne regiony Polski) nie są oczywiście tymi właściwymi sentymentalnymi „Kresami”, do których wspomniana narracja się odwołuje ${ }^{3}$.

\section{Meandry i fantazje polskich podmiotów postkolonialnych}

Jednym z tekstów, który nie zawsze w sposób jawny wydaje się organizować krajowe debaty „post” (-kolonialne, -zależnościowe czy wreszcie -komunistyczne), są Notatki o samo-kolonizujacych się kulturach Alexandra Kiosseva (Kiossev 1999), uszczegółowione później dla internetowej encyklopedii (Kiossev 2011). Tekst skupiony jest wokół spostrzeżenia, że peryferyjni dyskutanci, przedstawiciele podporządkowanych kultur, znajdując się w tej pozycji, widzą samych siebie i te własne kultury oczami dominujących aktorów, kultur uznanych i rozpoznawanych jako dominujące. Ten wątek badany był przez Marię Todorovą (Todorova 1997) w Wyobrażonych Bałkanach, Larry'ego Wolffa (Wolff 1994) w Wynajdywaniu Europy Wschodniej, a spośród polskich badaczy interesująco rozwijany przez Tomasza Zaryckiego (Zarycki 2010, 2014) w tym także w odniesieniu do imaginacji wewnątrzpolskich dotyczących statusu i wyobrażeń poszczególnych regionów. Kultury dominujące, a dokładniej (co jest dość istotnym rozróżnieniem) ta ich postać, jaką wyobrażają sobie miejscowe elity (literackie czy naukowe dla przykładu), stają się normatywnym wykładnikiem nie tylko tego, jak należy przedstawiać kultury (bądź ich konkretne artefakty), ale też co to jest właściwa kultura, literatura czy właściwie „kulturalny sposób bycia”. Zjawisko to owocuje deficytem „autentyczności”. Poczucie braku własnej (choćby i „barbarzyńskiej”) tożsamości staje się paradoksalnym fundamentem takich samokolonizujących się kultur i ich przedstawicieli. Wątek ten często bywa instrumentalnie używany w starciach politycznych wraz z innymi elementami retoryki postkolonialnej na oznaczanie wrogich, kolaborujących bądź wprost podporządkowanych, jeśli nie finansowo to „moralnie” (bądź intelektualnie) uznanych za niewłaściwych, błądzących przedstawicieli (najczęściej) elit. Faktycznie jest to przypadłość całego obszaru kulturowego i jego uczestników, więc niewyłącznie tylko tych, którzy są zafascynowani np. „obcymi ideami”, zaś akty poszukiwania tej właściwej, „natywnej” (wrodzonej, oryginalnej) autentyczności obnażają istotne w tej materii niedostatki. Jednym z autorów akcentujących silną zależność dyskursu postkolonialnego w Polsce od starć politycznych i pozycji politycznych poszczególnych wypowiadających się jest wspomniany wcześniej Tomasz Zarycki.

Charakterystycznym elementem tej nieuchronnej polityzacji dyskursu postkolonialnego, nieuchronnej, gdyż debata postkolonialna sama w sobie

\footnotetext{
Wątek ten i konsekwencje identyfikowania peryferyjnych i głównie imaginacyjnych obiektów jako centralnych poruszałem w innym miejscu (Kubiak 2015).
} 
zawiera istotny pierwiastek polityczny od samego początku, zaczynając choćby od emancypacyjnej politycznie treści Wyklętego ludu ziemi Frantza Fanona (1985), jest obecność silnego w nich elementu antyrosyjskości. O ile pozostałe mocarstwa zaborcze (Niemcy i Austria) raczej rzadko i epizodycznie występują bezpośrednio w roli kolonizatorów w narracjach postkolonialnych, historyczne Imperium Rosyjskie, Rosja współczesna i Związek Radziecki przewijają się w niej stale. Jest to przypadłość charakterystyczna dla całego regionu, związana z mocno sporną identyfikacją „postkomunizmu” z „postkolonializmem” (Moore 2001, Tlostanova 2012). Identyfikacja ta, nie licząc oczywiście doraźnych retoryk stricte politycznych, niesie ze sobą dwa dość poważne problemy.

Pierwszym i być może najbardziej rzucającym się w oczy jest nie tylko polaryzacja wokół wyobrażonej osi, jaką stanowi „postkomunizm” wraz ze wszystkimi nieuchronnymi uproszczeniami, jakie są związane z tym terminem, a które wedle Mirosławy Grabowskiej (Grabowska 2004) pozostawały fundamentem organizacji dyskursu politycznego (m.in.) w Polsce po roku 1989, ale także - co w szerszej perspektywie wydaje się istotniejsze - praktyczna delegitymizacja dyskursu lewicowego (bądź ogólniej: nieprawicowego) w krajach Europy Środkowo-Wschodniej. Dalej zaś - w szerszej perspektywie delegitymizacja Rosji jako państwa per se i niemal obsesyjne przywiązanie, charakterystyczne dla utrwalonego poczucia podrzędności, organizacji znacznej części narracji (i oczywiście działań politycznych) krajów dawnego bloku wschodniego wokół „problemu rosyjskiego”.

Drugim zaś jest problematyczny status Rosji (i Związku Radzieckiego) jako imperialnego aktora porównywalnego z klasycznymi kolonialnymi historycznymi potęgami, takimi jak choćby XIX-wieczna Anglia. Specyfika imperium-kolonizatora pozbawionego typowych (zamorskich) kolonii i w związku z tym orientującego się na lądową „wewnętrzną kolonizację”, była podejmowana wielokrotnie (Etkind 2003, 2011, Kagarlicki 2012, Morozov 2015). Wspomniany wyżej Jan Sowa na podobnej matrycy (i to podobieństwo było jedną z przyczyn kontrowersji wokół tej książki) oparł swój koncept Rzeczpospolitej Obojga Narodów jako lokalnego, półperyferyjnego imperium kolonialnego. Wszakże problem, szczególnie z lokalnej (m.in.) polskiej perspektywy, leży w tym, że - jak wielokrotnie zwracał uwagę Tomasz Zarycki - pozycja Rosji (i szczególnie Związku Radzieckiego) była i pozostaje relatywnie niska w stosunku do historycznych potęg kolonialnych. De facto prowadzi to do charakterystycznego przemieszczenia. W klasycznym, znanym choćby właśnie z klasyków, takich jak Said (Said 2009), kultura uznająca się za wyższą i rozpoznana w wyniku podboju i dominacji jako „wyższa” (gdzie ta wyższość legitymizowana jest po prostu siłą) dominuje „niższą”, wytwarzając charakterystyczne mechanizmy podporządkowań opisywane np. przez Bhabhę $(1984,1994)$ jako "mimikra” (upodobnienie podporządkowanych do dominujących) czy „hybrydyzacja” (wytwarzanie podporządkowanych form pośrednich, mieszanych, często później identyfikowanych jako 
„imitacje”) bądź „szyderstwo” (oryg. mockering) jako strategię defensywną podporządkowanych. Wszakże w przypadku analiz dotyczących tak historycznej Rosji, jak i Związku Radzieckiego, mamy do czynienia z imperium rozpoznawanym przez zdominowanych jako kulturalnie niższe, co prowadzi do charakterystycznych antynomii, pozwalających uznawać jednocześnie wielkość Puszkina czy Dostojewskiego i utożsamiać rosyjskość (w postaci praktycznie rasistowskiej zaś „ruskość”) z barbarzyństwem, więc z definicji z brakiem jakiejkolwiek „kultury” ${ }^{4}$. Dalsze konsekwencje tej skupionej wokół „rosyjskiej kolonizacji Polski” narracji, identyfikującej również bezpośrednio dominację ZSRR nad krajami bloku wschodniego jako wprost kolonialną, jest rodzaj „barbaryzacji” kategorii, jakich używa się podczas tego opisu (mimikra, hybrydyzacja) - krótko: każdy wpływ i każda relacja zostaje zidentyfikowana jako barbaryzująca, także wtedy, jeśli historycznie (jak np. historyczny „komunizm”) miały one charakter progresywny i faktycznie, w sensie normatywnym, europeizujący bądź „cywilizujący”5.

Dorota Kołodziejczyk szkicowane wyżej zagadnienie - wraz z pedagogiczną misją, jaką nadaje studiom postkolonialnym Dariusz Skórczewski (Skórczewski 2013, 98), autor silnie inspirowany pisarstwem Ewy Thompson - opisuje jako przekształcanie się emancypacyjnej narracji postkolonialnej w lokalną postać natywnego (a w praktyce: nacjonalistycznego) zamknięcia:

Narodowa pedagogika przekształca się z misji ukształtowania podporządkowanego w naród we wprost nacjonalistyczny dyskurs w prawicowych mediach. W nich podmiot narodowy przywracany jest do swego autentycznego źródła i przybliżany poprzez to, czym nie jest: niepoprawny politycznie, nie poddający się europejskim modom jak tęczowa czy genderowa ideologia, nie skłaniany do wpuszczania „islamistów” do kraju i zastępujący „pedagogikę wstydu” i „antypatriotyczny rewizjonizm” właściwą polityką historyczną (Kołodziejczyk 2017, 19)6.

Efektem tego jest charakterystyczne przekształcenie refleksji postkolonialnej, taki jej użytek, który „być może nieuchronnie w pewnych przypadkach, umacnia i legitymizuje nacjonalistyczny i autokratyczny zwrot w polityce Europy Centralnej, z Polską jako wiodącym przykładem" (Kołodziejczyk 2017, 19). Tym samym, jak zwrócił uwage Stanley Bill, „teoria postkolonialna oferuje gotowe instrumenty dla otwarcie konserwatywnych dążeń

\footnotetext{
4 Jest w tym jednak także pewna dwuznaczność; w odróżnieniu od innych „barbarzyńca” nie musi się przejmować swoim „brakiem kultury” bądź kulturowym niezorganizowaniem czy niepewnością, w wyobraźni podporządkowanej takiej wizji przewagą zasadniczą „barbarzyństwa” jest brak niespójności trapiący np. podporządkowane kultury wyższe (dajmy na to: „kulturę polską”). W tej mierze „barbarzyńskość” bywa w pewien sposób fascynująca, używając kolokwialnej idiomatyki, rzec można, że taki „barbarzyński ruski” nie musi się przejmować tym, czy jest „bardziej zachodni czy wschodni”, ani niczego „udawać” czy „starać się”, lecz „pijąc wódkę i śpiąc z niedźwiedziem” po prostu sobie „jest”.

W dominującym dziś typie wyobraźni identyfikującym PRL bądź jako „czarną dziurę” (więc obiekt, w którym wszystko „zanika”), bądź też jako okres o charakterystyce iście diabolicznej, stwierdzenie to może wydawać się niemal obrazoburcze. Niemniej progresywny i emancypacyjny charakter komunizmu jako historycznej ideologii jest czymś, co trudno ignorować, podobnie jak progresywne i emancypacyjne fakty społeczne czy działania podjęte w realiach PRL.
}

Wszystkie tłumaczenia cytatów pochodzą od autora tekstu. 
broniących ekskluzywności i esencjalnych wizji autentycznej kultury przeciw uniwersalistycznym postulatom" (Bill 2014).

Dopiero na tym tle wydaje się, że jeden z charakterystycznych motywów eksploatowanych $\mathrm{w}$ nurcie postkolonialnym, także stanowiąc istotny element literatury, mianowicie motyw zawieszenia i nieokreślenia, w jakim znajduje się Polska (bądź szerzej: cały region Europy Środkowo-Wschodniej) ${ }^{7}$, referowany jako „między Wschodem a Zachodem”, można pokazać w jego charakterystycznej lokalnej postaci. Narracja, którą przedstawiał Witold Gombrowicz o Polsce jako „Wschodzie dla Zachodu i Zachodzie dla Wschodu", wydaje się zarówno od wewnątrz (lokalnie), jak i z zewnątrz cokolwiek problematyczna. „Zachód” rozumiany jako kulturowy idiom, co pokazują właśnie analizy Larry’ego Wolffa (Wolff 1994), miał (i ma) dość zasadniczy problem z identyfikacją tego „pomiędzy” jako swoistej, odrębnej jakości. O ile - w pewnej mierze i dla pewnej warstwy np. niektórych rosyjskich bądź radzieckich intelektualistów - część tego stwierdzenia („Polska jako Zachód dla Wschodu”) może być w dorzeczna, przynajmniej okresowo ${ }^{8}$ - o tyle druga część tej metafory zawiera w sobie istotną problematyczność. „Polska” dla „Zachodu” niekoniecznie jest obecna jako jakikolwiek pośrednik względem „Wschodu”, ten bowiem jest identyfikowany z zachodnim wyobrażeniem „Wschodu” jako Rosji i konsekwentnie obrazy tego, co „wschodnie”, czerpane są z literatury rosyjskiej. Jest to okoliczność, którą Dariusz Skórczewski $(2013,329)$ zinterpretował jako kolejny gest orientalizacji powielający wykluczenie podporządkowanych (w tym przypadku kraje i społeczności zdominowane przez Rosję czy później Związek Radziecki). Taka interpretacja tekstu Wolffa pozostaje wszakże wątpliwa, by nie rzec: opaczna. Intencją Wolffa było ukazanie, w jaki sposób wyobraźnia dominujących aktorów: siedemnastowiecznych podmiotów politycznych i ich np. literackich heroldów nadających tej właśnie dominującej wyobraźni status rzeczywistości („faktów”), wyklucza jakikolwiek głos podporządkowanych, redukując ich egzystencję do folkloru lub rebelii „dzikich” (bądź niemal „dzikich”). Skórczewski w ten sposób, wbrew swoim ambicjom, pomija dekonstrukcyjny wysiłek autora Wynajdywania Europy Wschodniej.

Temat procesu konstrukcji „wschodniości” podjął także Zarycki (Zarycki 2014), wskazując, w jaki sposób różne, konkurujące ze sobą lokalne elity współkreują ten idiom zarówno na użytek wewnętrzny, jak i „dla Zachodu”. Tematyka ta - podejmowana także w kontekście regionalnym (Zarycki $2008,2009,2010)$ i regionalnej idiomatyki - wydaje się nader istotna także dlatego, że wychodzi poza krąg analiz „kompradorstwa” czy „mimikry” bądź „imitacji”; ogólniej: pojęciowości silnie związanej z postkolonialną

Co interesujące, ale całkowicie zrozumiałe, gdyż życie społeczne pełne jest takich sprzeczności, nurt ten w niczym nie zakłóca narracji związanych z „autentycznością” (natywnością).

Takim przypadkiem będzie choćby właśnie okresowo polskie pośrednictwo $\mathrm{w}$ dostępie zachodniej literatury dla części radzieckich intelektualistów. Rzecz - co warto zaznaczyć, choć wydaje się oczywista - związana z represyjnym charakterem ZSRR jako państwa nie zaś z jakąkolwiek „kulturową koniecznością” takowego pośrednictwa. 
wyobraźnią i politykami tej wyobraźni, a także związanymi z nimi uproszczeniami prowadzącymi do powielania wyobrażenia o bezpośrednim odziedziczeniu przez poszczególne regiony współczesnej Polski ich statusów (bądź „natur”) z okresu rozbiorowego.

\section{Wewnętrzne kolonialności}

„Wnętrze” szkicowanego wyżej problemu bycia „pomiędzy” wydaje się silnie związane ze statusem części lokalnych elit, czyli w przypadku Polski, Rosji czy innych krajów regionu, warstwy identyfikowanej jako „inteligencja" (wszakże sama ta identyfikacja grupowa jest więcej niż problematyczna i jest także istotną stawką polityczną). Rzecz dość oczywista już choćby z tej przyczyny, że „tożsamość kulturowa” jak i wątpliwości związane z umieszczeniem Polski, jej kultury czy populacji jest problemem dla tej właśnie warstwy. Dla pozostałych zaś może być problematyczna np. ze względu na (niewyłącznie) ekonomiczne nierówności, natomiast niekoniecznie będzie już „problemem tożsamości”. Ten tożsamościowy dramat można, przynajmniej w odniesieniu do wspomnianej „inteligencji”, do pewnego stopnia traktować jako pochodną, jak wskazuje Zarycki (Zarycki 2008), odmiennego pochodzenia (Chałasiński 1946) samej tej warstwy, jak i specyfiki związanej z jej cechą definicyjną: silnym kapitałem kulturowym połączonym z niedostatkiem kapitału ekonomicznego.

W koncepcji trzech zasadniczych kapitałów ${ }^{9}$ Pierre'a Bourdieu (Bourdieu 1986), do jakiej się w swojej interpretacji odwołuje Zarycki, kapitał ekonomiczny stanowi najbardziej podstawową (choć niekoniecznie występująca w obiegowo „ekonomicznej” np. pieniądzu) formę zakumulowanej pracy. Kolejne bardziej skomplikowane formy kapitału, jak społeczny (obejmujący np. sieć połączeń rodzinnych, znajomości, dostęp do towarzystwa jako zasobu) czy kulturowy (w tej części znajdują się zarówno łatwo identyfikowalne zasoby kulturowe zdobywane w drodze edukacji jak i artefakty kulturowe, takie jak np. książki, dzieła sztuki i związane z nimi aktywności), wymagają dłuższej i bardziej skomplikowanej akumulacji (ale też wedle Bourdieu cechują się większą trwałością). Według Zaryckiego cechą charakterystyczną inteligencji jako warstwy posiadającej (przynajmniej w przeszłości) dominującą rolę w definiowaniu normatywności w społecznościach Europy Środkowo-Wschodniej jest właśnie - odrębnie od elit wykształconych w krajach Zachodu - słaba obecność kapitału ekonomicznego. Słabość ta, która bywa reprezentowana jako swoista postać „niezależności” (choć faktycznie oznacza właśnie wyjątkowo głęboką zależność od dysponentów kapitału ekonomicznego i nieuchronność relacji klienckich), powoduje charakterystyczną dla Europy Środkowo-Wschodniej niepewność ekonomiczną warstw kulturowo dominujących (więc wyznaczających to, co „jest” bądź

\footnotetext{
$9 \quad$ Pomijam tutaj istotne dla teorii Pierre'a Bourdieu kategorie pola czy habitusu dla prostoty wywodu, co upraszcza zarówno referowane stanowisko Zaryckiego, jak i koncept Bourdieu.
} 
„nie jest” kulturą i przynajmniej częściowo mających wpływ na instytucje dyscyplinujące, takie jak np. szkoła). „Kwestia tożsamości” - kategoria należąca do kapitału kulturowego i związane z nią podziały - często w konsekwencji funkcjonująjako zastępstwo podziałów klasowych. Nieprzypadkowo „ruskość” (podobniejak ogólniej „wschodniość”) identyfikowanajestz biedą, zacofaniem i niedostatkami kulturowymi, co niekoniecznie ma związek ze stanem faktycznym. W konsekwencji Zarycki skłania się do identyfikacji lokalnych sporów o „wschodniość” czy „zachodniość” jako starcie między zagrożoną inteligencją a konkurującymi z nią innymi warstwami aspirującymi do kulturowej dominacji (np. nową warstwą profesjonalistów), faktycznie będącymi - przynajmniej przez proces socjalizacji i inkulturacji (np. w drodze szkolnej) - jej częścią.

Kwestia statusu inteligencji w debacie postkolonialnej i postkolonialnych praktykach kontestacji, oporu bądź - jak w przypadku narracji sentymentalnej - afirmacji (własnych form kolonialnych) jest o tyle istotna, że uczestnikiem i głównym aktorem takich debat (i praktyk) są różne frakcje tejże inteligencji zarówno jako „podmiot mówiący/piszący”, jak i „przedmiot” poddany presji kolonizacyjnej/dekolonizacyjnej. Skomplikowane relacje wewnątrz tej warstwy jak i interesującą koncepcję jej ewolucji przedstawili wspólnie Smoczyński i Zarycki w książce Totem inteligencki. Arystokracja, szlachta, ziemiaństwo w polskiej przestrzeni społecznej (Smoczyński, Zarycki 2017), tematyką tą zajmuje się także np. Piotr Kulas (Kulas 2017) zaś w kontekście miejskim np. Piotr Kubicki (Kubicki 2011, 2011a). Problem ten wydaje się także szczególnie istotny z tego względu, że jeśli refleksję na temat form identyfikuje się jako „dekonstrukcję kodów ucisku” (Babkou 2013, 21), o tyle jej polska praktyka często zmierza w innym kierunku. Jak zwracają uwagę przywołani wcześniej Dorota Kołodziejczyk i Stanley Bill, dyskurs postkolonialny przynajmniej w części przybrał postać rekonstrukcyjną, stając się $\mathrm{w}$ ten sposób narzędziem do potępienia cudzego kolonializmu (zwłaszcza rosyjskiego) jako immanentnie złego, własny zaś przedstawiając jako dobroczynny. Ma to swój nie tylko wydźwięk międzynarodowy (z całą paternalistyczną i silnie instrumentalną „polityką wschodnią” uprawianą praktycznie przez wszystkie polskie rządy i większość publicystów), ale także wewnętrzny. Przykładem tego ostatniego mogą być próby restytucji, silnie anachroniczne, „miejskości” i „mieszczaństwa” jako kategorii różnicujących i stabilizujących anachroniczną, faktycznie nie „konserwatywną”, lecz raczej „reakcyjną” wizję możliwie trwałych podziałów społecznych (Kubiak 2017) ${ }^{10}$. Podziały te, zarówno rekonstruowane, jak i kreowane (choćby w retoryce „słoików” czy „sprzedających się za plus pięćset”), wciąż zachowują tak samo silny, jak iluzoryczny charakter terytorialny związany z wyobraźnią regionalną i orientalizacyjnym spojrzeniem na „wewnętrzny wschód”, wszakże nie mniej istotny wydaje się aspekt podziałów społecznych niż podziałów terytorialnych.

$10 \quad$ Wspomniany wyżej Michał Buchowski (2006) wskazywał, w jaki sposób po roku 1989 retoryki orientalizacyjne zaczęły funkcjonować jako element wyznaczania tych podziałów i podporządkowań. 
Osobliwość i trwałość statusu inteligencji i jej specyficznego ethosu, odmiennego od uznawanego za "typowe” mieszczaństwa czy nieco mniej typowych przedstawicieli francuskich les Intellectueles ${ }^{11}$ (w zasadniczych sferach dość bliskiej swej rosyjskiej postaci), Zarycki upatruje w specyficznym połączeniu separacji stanowej i przesunięcia ziemiaństwa na pozycje symboliczne, wraz ze zbiorowym procesem awansu dokonanego wraz z restauracją państwa w roku 1918 i kontynuowanym w $P R L^{12}$. Starcie o hegemonię symboliczną (i skuteczną kontrolę związanych z nią zasobów ) między warstwami szlachecko-ziemiańskimi a inteligencją wygrała inteligencja:

Ostateczną wygraną inteligencji nad ziemiaństwem był moment powstania PRL, czemu towarzyszyło przyjęcie kolejnej, silnie inteligenckocentrycznej instytucjonalizacji etosu obywatelskiego. Pomimo robotniczo-chłopskiej retoryki władze komunistyczne PRL, w przeciwieństwie do Związku Radzieckiego, nie zdecydowały się na odejście od kluczowych wartości inteligenckiego wariantu powszechnej nobilitacji (Smoczyński, Zarycki 2017, 205).

Wspomniana „osobliwość” i „trwałość” związana jest wedle przywołanych autorów ze skutecznym przejęciem przez inteligencję kontroli nad zasobami (kapitałami) symbolicznymi zbiorowości, co efektywnie redukuje „szlacheckość”, niezależnie od empirycznej obecności przedstawicieli potomków tego stanu, do tytułowej roli „totemicznej”, gdzie aspiracje do "szlacheckości" w wymiarze zbiorowym i sentymentalnym zaspokajane mogą być przez zbiorowe uczestnictwo (i wraz z nim identyfikacje) w „przeżyciu szlacheckim”: od literackiego i filmowego Potopu, przez „przodków wynalezionych” i sentymentalizm kresowy, do uniwersalizacji formy „Pan”, „Pani”.

Powszechna nobilitacja (przez formy „Pan”/„Pani”), jaka funkcjonalnie zastąpiła obywatelskość, spowodowała „uniwersalizację i swoistą dekontekstualizację opozycji ,pan/cham'” (Smoczyński, Zarycki 2017, 212), która z opozycji stanowej stała się opozycją polityczno-egzystencjalną: „cham” jest efektywnie odpowiednikiem „nieobywatela”, kogoś nie tylko (bądź „nie tyle”) pozbawionego uznawanych za właściwe i konieczne kompetencji, lecz przede wszystkim niezdolnego do sprawowania władzy politycznej, ogólniej zaś: pozbawionego głosu (i prawa do głosu). Granicznie

11 Potoczne (szczególnie w fantazjach mieszczańskich) wyobrażenie „mieszczaństwa” jako uniwersalnej ekonomicznie i politycznie kategorii społecznej, właśnie „typowej” dla Zachodu, jest tak samo popularne, jak mylące. Zarówno historyczny, jak i współczesny status różnych warstw mogących być nazywane mieszczaństwem, w krajach Europy Zachodniej był różny (np. mieszczaństwo francuskie było czymś jednak innym niż brytyjskie czy niemieckie). Istnieje też poważna wątpliwość, czy ta kategoria ma w ogóle sens w przypadku Stanów Zjednoczonych i krajów pozaeuropejskich, w tym dawnych kolonii.

12 Kategoria „ziemiaństwa”, szersza niż szlachta, ukuta w II Rzeczpospolitej, obejmuje nieszlacheckich (bądź takich, których szlacheckie pochodzenie budziło wątpliwości) znaczących posiadaczy kapitału ziemskiego, warstwa ta została efektywnie włączona do stanu politycznie i społecznie uprzywilejowanego w II RP. Awans, o którym mowa, miał charakter symboliczny, pozwalał na korzystanie przez ziemiaństwo (i dalej inteligencję) z pewnych zasobów symbolicznych szlachty (takich jak retoryka, zwyczaje i standardy językowe, kody zachowania, ubioru, form identyfikacji stanowej, w części także przypadków dostęp do wspólnego pola matrymonialnego itd.) w sposób zalegitymizowany („symbolicznie legalny”). Okoliczność istotna dlatego, że przy braku tej legitymizacji awans byłby tylko uzurpacją. Tę np. imputuje się części współczesnych warstw inteligenckich przy użyciu terminu „łżeinteligencja” (innym terminem o podobnym charakterze jest np. „lumpeninteligencja”). 
zaś: pozbawionego prawa do współuczestnictwa we właściwej, konstruowanej symbolicznie jako szlachecko-inteligencka, wspólnocie polskiej, co rekonstruowane jako wewnętrzna niemożliwość (ten „cham”, co nigdy nim być nie przestaje), ma cechy bliskie rasistowskim. Ostatecznie: opisywana przez Zaryckiego i Smoczyńskiego powszechna nobilitacja efektywnie przyjęła postać symbolicznych, zbiorowych i rozległych wykluczeń i orientalizacyjnych stereotypizacji, bardzo wyraźnych w II Rzeczpospolitej, owocnie transmitowanych w okresie Polski Ludowej i ze znacznym entuzjazmem rekonstruowanych po roku 1989 (Kubiak 2017, 2017a) ${ }^{13}$.

Użyteczną być może dla ilustracji tej pułapki nobilitacyjnej będzie tu zarówno narracyjna postać „mieszkańców byłych PGR”, jak i „słoików”14. Pierwsi są przykładem introdukcji narracji represji jako „grzechu pierworodnego" (gdzie z okoliczności niezależnych od obiektu czyni się jego cechy własne, niezbywalne i zwykle dziedziczne, zabieg charakterystyczny dla dyskursów przemocy). Ich „roszczeniowość” ${ }^{15}$, „lenistwo”, „zacofanie” (oraz pozostała kolekcja tak rzeczywistych, jak i urojonych przywar) ma charakter na tyle popularnego w Polsce w tej chwili idiomu, że zasadniczo nie wymaga komentarza. Na szerszą skalę ta „postpegeerowa” klasyfikacja ma charakter zgeneralizowany jako „Polska B”16, identyfikowana tak samo typowo, jak niesłusznie głównie ze wschodnimi regionami kraju. Ta ostatnia, mającą faktycznie postać bardziej społeczną niźli terytorialną, w skali państwa może być do pewnego stopnia identyfikowana z tym, co Milica Bakić-Hayden (1995) określiła w kontekście Jugosławii jako „zagnieżdżony orientalizm”. Komponenty społecznych nierówności, zarówno anachronicznie rekonstruowane, jak i kreowane, wydają się nie mniej istotne. „Orientalizm” wewnętrzny i procesy orientalizacyjne stanowią wszak element kształtowania społecznego, a granicznie: rasowego (Bobako 2010, Buchowski 2006) zróżnicowania.

Jak zasadnicza większość kategorii orientalizujących „chamskość” ma, jak wspomniane zostało wcześniej, charakter „ontologicznego grzechu pierworodnego", to znaczy, że nie tylko jest „cechą własną”, lecz również podlega dziedziczeniu. Widać to dobrze na przykładzie przywołanych wyżej „słoików”. Popularnej (przynajmniej w pierwszej dekadzie XXI wieku)

\footnotetext{
13 Debata „chamsko-pańska” jest rzecz jasna daleko bardziej obszerna, nic w tym dziwnego, gdyż stanowi istotny element organizacji tak wyobraźni, jak i polityk poszczególnych grup. Była też (i wciąż jest) elementem stricte literackich badań i dyskusji (zob. np. Błoński 1981), które pozwalam sobie tu pominąć z tej racji, że intencją tego tekstu jest wyprowadzenie Czytelnika poza pole literatury i literaturoznawstwa właśnie.

14 Podobną charakterystykę ma również kategoria „pięćsetów” (domniemanych wyborców PiS „sprzedających Polskę za „+500”) identyfikowana, nader fałszywie, z wiejską i małomiasteczkową właśnie „postpegeerowską” i „postkomunistyczną” grupą „dziedzicznych chamów”.

15 Co również charakterystyczne dla dyskursów przemocy, zgłaszanie roszczeń jako takich jest immanentnie niewłaściwe (jeśli nie niegodziwe) bez refleksji, czy są one słuszne czy nie, z „istoty” są niesłuszne, skoro podnoszone przez „roszczeniowców”.

16 Wbrew dość często pojawiającym się wyobrażeniom umiejscawiającym obfitość instytucji PGR i ich nieuchronnie katastrofalnych efektów w „Polsce B” (identyfikowanej jako wschodnie regiony kraju) relatywnie największe gospodarstwa tego typu znajdowały się na terenie Pomorza, nie brakowało ich także oczywiście w Polsce zachodniej.
} 
kategorii służącej do opisywania przyjezdnych z „Polski B”, szukających możliwości realizowania swoich ambicji bądź choćby godziwego życia głównie w Warszawie. Symboliczną „nagrodą” za to, że miast poddać się pierwotnej stereotypii, przyjmują na serio np. modernizacyjną opowieść o polskich self-made manach, jest przypomnienie im ich „właściwego miejsca” i tego, że niezależnie od wysiłków, „cham” zawsze w nich pozostanie ${ }^{17}$.

O ile za inauguracyjny, w pewnej mierze, tekst dla polskiej debaty stricte postkolonialnej często jest uznawany artykuł Claire Cavannagh (Cavannagh 2003) Postkolonialna Polska. Biała plama na mapie współczesnej teorii, to nie znaczy, że refleksja dotycząca asymetrii relacji między Europą Środkowo-Wschodnią a Zachodnią czy też kwestii relacji kolonialnych i parakolonialnych była nieobecna wcześniej ${ }^{18}$. Współczesna dynamika tego dyskursu przesunęła się w stronę prób ustalenia stabilnego, kontrolowanego obrazu „postkolonialności”. Dotyczy to wyraźnie badań i zagadnień znajdujących się w szerszym polu niźli standardowa (nomen omen) literatura postkolonialna, skupiona głównie wokół literatury właśnie. „Stawki postkolonialności", jeśli się można tak wyrazić, nigdy nie należały wyłącznie do sfery badań literaturoznawczych, pisarstwo klasyków literatury postkolonialnej od początku miało wyraźny charakter interwencji politycznej, choć podejmowanej i akcentowanej w różny sposób. Wspólnym mianownikiem tej literatury, od Fanona i Saida do Chakravorty-Spivak czy Bhabhy, była zawsze intencja emancypacyjna. Problem, przed jakim stanął nurt tej refleksji w XXI stuleciu, także w Polsce, to odwrót od uniwersalistycznie rozumianej emancypacji: wizji świata, który zrozumiał swoje kolonialne dziedzictwo i umiał się wyrzec jego beneficjów na rzecz równości, w kierunku partykularnej konkurencji o (faktycznie podporządkowaną) hegemonię symboliczną pozwalającą na kreowanie nowych i umacnianie istniejących podrzędności w lokalnym wymiarze.

Ten nurt lokalnie rozpoznać można w kreacjach różnych typów „Polski”, a w konsekwencji różnych typów Polaków (i nie-Polaków, przy czym granice podziałów, choć silne deklaratywnie, w praktyce bywają okazjonalne

${ }_{17}$ W tym przypadku także mieści się znacząca dwuznaczność. Kategoria „słoika” (czy małopolskiego „krzaka”) służy do separacji nowo przybyłych jako narzędzie podkreślania swoich uprawnień i legitymizowania ich. Wszak zdecydowana większość „rodowitych warszawiaków” jest nimi (w najlepszym przypadku) zaledwie od pokolenia bądź dwóch. Przybyszy i ich stygmatyzację legitymizuje więc ich własna „zasiedziałość”, która - o czym być może boleśnie się przekonali - nigdy nie będzie „dość zasiedziała”, by zyskać akceptację tych „prawdziwie zasiedziałych”. W drugiej dekadzie XXI wieku ta retoryka przesunęła się w stronę otwarcie rasistowskiej, kierując się przeciw (głównie wyimaginowanym) imigrantom.

18 Kwestia datowania „debaty postkolonialnej” w naturalny sposób może być przedmiotem istotnych sporów. W zależności od przeświadczeń poszczególnych autorów można za taki początek uznać pierwsze tłumaczenie Orientalizmu Edwarda Saida (1991) czy polskojęzyczne wydanie Trubadurów imperium Ewy Thompson (2000). Nie sposób też nie wspomnieć o refleksji Marii Janion (Polska miedzy Wschodem i Zachodem 2003) i jej własnego projektu dekolonizacyjnego od-pisywania (Niesamowita słowiańszczyzna 2006). Czytelnik zorientowany mniej literaturoznawczo zapewne wskazałby teksty Witolda Kuli (Historia, zacofanie, rozwój 1983) czy Teorię ekonomiczna ustroju feudalnego z 1962 roku. Ważniejsze niż konkretne datowanie wydaje sie umiejscowienie tej narracji na polskiej mentalnej mapie i wskazanie, w jaki sposób funkcjonuje ona nie jako przedmiot teorii (i teoretycznych sporów), lecz jako element zbiorowej wyobraźni i niebagatelnych stawek w starciach politycznych i społecznych (więc poza sferą „teoretycznej niewinności”). 
i instrumentalne), gdzie retoryka ostatnich lat jest może najbardziej wulgarna, lecz raczej mało odkrywcza czy nowatorska. Niebezpieczeństwo takiej „postkolonialnej pętli”, w której dyskurs emancypacyjny zaczyna przybierać formę represji, stanowi być może jedno z najpoważniejszych wyzwań po ponad dziesięciu już latach „debaty postkolonialnej”.

\section{Bibliografia}

Babkou Ihar, 2013, Na wschód od centrum - konfiguracje nowoczesności na wschodnioeuropejskim pograniczu, w: Polska wschodnia i orientalizm, Zarycki T. (red.), Warszawa.

Bakić-Hayden Milica, 1995, Nesting Orientalisms: The Case of Former Yugoslavia. „Slavic Review”, nr 54 (4), s. 917-931.

Beauvois de Daniel, 2005, Trójkat ukraiński. Szlachta, carat i lud na Wołyniu, Podolu i Kijowszczyźnie 1793-1914, Rutkowski K. (przeł.), Lublin.

Bhabha Homi K., 1984, Of Mimicry and Man: The Ambivalence of Colonial Discourse, „October”, nr 28, s. 125-133.

Bhabha Homi K., 1994, The Location of Culture, Routledge, London \& New York.

Bill Stanley, 2014, Seeking the Authentic: Polish Culture and the Nature of Postcolonial Theory, nonsite.org/article/seeking-the-authentic-polish-cultureand-the-nature-of-postcolonial-theory (dostęp: 2018.04.10).

Bill Stanley, 2017, Position Paper: Postcolonial Theory and Poland, w: Unforeseen Constellations: Reading Postcololnial Poland with South America, Polish Studies Center Indiana University, Bloomington, materiały konferencyjne, s. 56-64.

Błoński Jan, 1981, Mędrek, cham i jednoaktówka, w: Romans z tekstem, Kraków, s. $181-215$.

Bobako Monika, 2010, Konstruowanie odmienności klasowej jako urasawianie. Przypadek polski po 1989 roku, (online:) https://www.academia. edu/1324358/Konstruowanie odmienno\%C5\%9Bci klasowej jako urasawianie. Przypadek_polski_po 1989 roku (dostep: 2018.04.10).

Bochuszewicz Piotr, 2011, Pożytki z prawicowego neosarmatyzmu. (Nieprawicowa) obrona Krzysztofa Koehlera, w: Biliński P. (red.), Przeszłość we współczesnej narracji kulturowej. Studia i szkice kulturoznawcze, Tom 1, Kraków, s. 99-117.

Bochuszewicz Piotr, 2014, Hermenutyki Sarmatyzmu, w: Lutomierski M. (red.), Tradycje szlacheckie we wspótczesnej kulturze polskiej. Przybliżenia i perspektywy badawcze, Torun, s. 105-130.

Bourdieu Pierre, 1986, The forms of capital, w: Handbook of Theory and Research for the Sociology of Education, Richardson J. (red.), New York, Greenwood, s. 241-258.

Buchowski Michał, 2006, The Specter of Orientalism in Europe: From Exotic Other to Stigmatized Brother, "Anthropological Quarterly", nr 79 (3), s. $463-482$. 
Cavannagh Claire, 2003, Postkolonialna Polska. Biała plama na mapie współczesnej teorii, „Teksty Drugie”, nr 2, s. 360-371.

Chałasiński Józef, 1946, Społeczna genealogia inteligencji polskiej, Warszawa.

Domańska Ewa, 2008, Obrazy PRL w perspektywie postkolonialnej. Studium przypadku, w: Obrazy PRL. Konceptualizacja realnego socjalizmu w Polsce, Brzechczyn K. (red.), Poznań, s. 167-186.

Etkind Alexander, 2003, Internal Colonization and Russian Cultural History, „Ulbandus” 7, s. 17-25.

Etkind Alexander, 2011, Internal Colonization. Russia's Imperial Experience, Cambridge, Malden.

Fanon Frantz, 1985, Wyklęty lud ziemi, Tygielska H. (przeł.), Warszawa.

Grabowska Mirosława, 2004, Podział postkomunistyczny. Społeczne podstawy polityki w Polsce po 1989 roku, Warszawa.

Janion Maria, 2003, Polska między Wschodem a Zachodem, „Teksty Drugie”, nr 4, s.19-42.

Janion Maria, 2006, Niesamowita słowiańszczyzna. Fantazmaty literaury, Kraków.

Kagarlicki Borys, 2012, Imperium peryferii. Rosja i system światowy, Leonkiewicz Ł., Szulęcka B. (przeł.), Warszawa.

Kiossev Alexander, 1999, Notes on Self-Colonizing Cultures. Art and Culture in PostCommunist Europe, Pejic B., Elliott D. (red.), Stockholm, Moderna Museet, s. 114-18.

Kiossev Alexander, 2011, Self-Colonizing Metaphor, Atlas of Transformation. Tranzit. http://monumenttotransformation.org/atlas-of-transformation/ html/s/self-colonization/theself-colonizing-metaphor-alexander-kiossev.html (dostęp: 2018.04.10).

Kołodziejczyk Dorota, 2017, Comparative Posts Going Political - the Postcolonial Backlash in Poland, w: Unforeseen Constellations: Reading Postcolonial Poland with South America, Polish Studies Center Indiana University, materiały konferencyjne, s. 12-22.

Kubiak Adam, 2015, Rzeczy mniejsze. Dysformia i fiasko: semi-peryferyjne formy kultury, Rzeszów.

Kubiak Adam, 2017, „Bieda (z ta Polska)”. Prostacy i mieszczanie: modernizacyjna naturalizacja i normalizacja peryferyjnych nierówności, „Polityka i Społeczeństwo”, nr 3 (15).

Kubiak Adam, 2017a, Inkluzywne wykluczenie i reprodukcja. Próba szkicu o szkole w zaburzonej modernizacji, w: Hańderek J., Kućma N., Wykluczenia. Perspektywy ponowoczesności, Kraków, s. 145-162.

Kubicki Paweł, 2011, Nowi mieszczanie w nowej Polsce, Kraków.

Kubicki Paweł, 2011a, Nowi mieszczanie - nowi aktorzy na miejskiej scenie, „Przegląd Socjologiczny”, nr 60 (2-3), s. 203-227.

Kula Witold, 1962, Teoria ekonomiczna ustroju feudalnego. Próba modelu, Warszawa. 
Kula Witold, 1983, Historia, zacofanie, rozwój, Warszawa.

Kulas Piotr, 2017, Inteligenckość zaprzeczona. Ethos I tożsamość młodych inteligenckich elit, Warszawa.

Moore David C, 2001, Is the Post- in Postcolonial the Post- in Post-Soviet? Toward a Global Postcolonial Critique, PMLA 116(1) s. 111-128 (online:) http://monumenttotransformation.org/atlas-of-transformation/html/p/ postcolonial-post-soviet/is-the-post-in-postcolonial-the-post-in-post-soviettoward-a-global-postcolonial-critique-david-chioni-moore.html (dostęp: 2018.04.10).

Morozov Viatcheslav, 2015, Russia's postcolonial identity: a subaltern empire in a Eurocentric world, Palgrave Macmillan, Houndmills, Basingstoke, Hampshire.

Pacholski Arkadiusz, 2012, Jak Polak zhańbił Polaka, czyli niewolnictwo po polsku (online:) http://wyborcza.pl/magazyn/1,127532,12346425, Jak_Polak zhanbil_Polaka_czyli niewolnictwo_po_polsku.html (dostęp: 2018.04.10).

Said Edward, 2009, Kultura i imperializm, Wyrwas-Wiśniewska M. (przeł.), Kraków.

Skórczewski Dariusz, 2013, Teoria-literatura-dyskurs. Pejzaż postkolonialny, Lublin.

Smoczyński Rafał, Zarycki Tomasz, 2017, Totem inteligencki. Arystokracja, szlachta, ziemiaństwo $w$ polskiej przestrzeni społecznej, Warszawa.

Sosnowska Anna, 2004, Zrozumieć zacofanie. Spory historyków o Europę Wschodnia (1947-1994), Warszawa.

Sowa Jan, 2011, Fantomowe ciało króla. Peryferyjne zmagania z nowoczesna forma, Kraków.

Terlouw C.P., 1993, The Elusive Semiperiphery: A Critical Examination of the Concept Semiperiphery, „International Journal of Comparative Sociology”, nr 34. s. 87-102.

Thompson Ewa, 2000, Imperial knowledge: Russian literature and colonialism, Westport, CT: Greenwood Press.

Thompson Ewa M, 2000a, Trubadurzy imperium. Literatura rosyjska i kolonializm, Kraków.

Thompson Ewa, 2007, W kolejce po aprobatę. „Dziennik”. Listopad 5. (online:) http://wiadomosci.dziennik.pl/wydarzenia/artykuly/59821,w-kolejce-poaprobate.html (dostep: 2018.04.10).

Thompson Ewa, 2010, Sarmatyzm i postkolonializm. O naturze polskich resentymentów, „Dziennik”. Październik 5. (online:) http://wiadomosci. dziennik.pl/wydarzenia/artykuly/193060,sarmatyzm-i-postkolonializm.html (dostęp: 2018.04.10).

Thompson Ewa, 2011, A jednak kolonializm. Uwagi epistemologiczne, „Teksty Drugie", nr 6, s. 289-302.

Tlostanova Madina, 2012, Postsocialist $\neq$ postcolonial? On post-Soviet imaginary and global coloniality, „Journal of Postcolonial Writing”,48/2, s. 130-142.

Todorova Maria, 2009, Imagining the Balkans, Oxford.

Polonistyka. Innowacje

Numer 8, 2018 
Wolff Larry, 1994, Inventing Eastern Europe: The Map of Civilization on the Mind of the Enlightenment, Stanford.

Zarycki Tomasz, 2008, Kapitał kulturowy. Inteligencja w Polsce i $w$ Rosji, Warszawa.

Zarycki Tomasz, 2009, Ku socjologicznej analizie dyskursu elit peryferyjnych, w: Wartości, polityka, społeczeństwo, Zahorska M., Nasalska E. (red.), Warszawa, s. 169-181.

Zarycki Tomasz, 2010, Peryferie: Nowe ujęcia relacji centro-peryferyjnych, Warszawa.

Zarycki Tomasz, 2014, Ideologies of Eastness in Central and Eastern Europe, Routledge, Londyn\&New York.

\section{O Autorze:}

Adam Kubiak, dr, zajmuje się zagadnieniami z pogranicza problematyki podporządkowania, nierówności i zależności oraz strategii podporządkowanego oporu, sytuując się między terytoriami badawczymi filozofii, kulturoznawstwa i nauk społecznych. Publikował m.in. w „Kwartalniku Filozoficznym”, „Tekstach Drugich” i „Polityce i Społeczeństwie”. Jest autorem książki Rzeczy mniejsze. Dysformia i fiasko - semi-peryferyjne formy kultury poświęconej specyfice lokalnej postkolonialności i jej narracjom. 
